\title{
Studi Ketercapaian KKNI Guru Fisika dan Refleksinya dalam Pembelajaran Berbasis Creative Skill
}

\author{
Muhammad Jhoni \\ Universitas PGRI Palembang. Jend. A. Yani, Seberang Ulu II, Kota Palembang, 30116, Indonesia \\ Korespondensi Penulis. E-mail: m.jhoni66@gmail.com \\ Received:10 January 2017; Revised:10 March 2017; Accepted: 10 April 2017
}

\begin{abstract}
Abstrak
Tujuan penelitian ini adalah mengungkapkan: (1) ketercapaian kompetensi guru fisika Prodi Pendidikan Fisika UNSRI terhadap KKNI dan (2) refleksinya dalam pembelajaran fisika berbasis creative skill. Penelitian ini merupakan survei yang dilakukan di Kota Palembang. Subjek penelitian 12 guru fisika di bawah lima tahun dari kelulusannya, 12 guru fisika senior, dan 364 siswa. Data dikumpulkan melalui angket, observasi, dokumentasi, dan wawancara, dianalisis dengan teknik deskriptif kuantitatif dan kualitatif. Hasil penelitian menunjukkan bahwa (1) ketercapaian kompetensi guru lulusan Prodi Pendidikan Fisika UNSRI sudah mencapai KKNI level enam dengan kriteria cukup untuk deskriptor pertama, baik untuk deskriptor kedua, ketiga, dan keempat, dengan keunggulan pada kompetensi memanfaatkan ICT, profesional dan pedagogik, bimbingan dan konseling, kompetensi sebagai guru fisika, kompetensi kepribadian dan sosial, dan kelemahan pada kompetensi menggunakan peralatan laboratorium, dan menerapkan penelitian pendidikan dalam pembelajaran fisika; serta (2) tingkat reflektifnya dalam pembelajaran fisika berbasis creative skill dalam kriteria baik pada dimensi produk, proses dan kepribadian guru.
\end{abstract}

Kata Kunci: kompetensi, guru fisika, KKNI level enam

\section{Study of Achievement INQF of Physics Teacher and Its Reflection in Creative Skill-Based Teaching}

\begin{abstract}
This research aims to reveal: (1) achievement of competence of physics teachers of Physics Education Program UNSRI toward INQF and (2) its reflection to the creative skill-based physics teaching. This research was a survey conducted in the Palembang city. The Subjects were 12 new physics teachers, 12 senior physics teachers, and 364 students. Data were collected through questionnaires, observation, documentation, and interviews, and analyzed with quantitative and qualitative descriptive. The results of research showed that (1) achievement of the competence of physics teachers has reached six level INQF with sufficient criterion for the first descriptors, and good criterion for the second, third and fourth descriptors, with competence strength in utilizing ICT, professional and pedagogic, guidance and counseling, as a physics teacher competence, personal competence and social competence and competence weakness in using laboratory equipment, and applying educational research; and (2) the level of reflection in the creative skill-based physics teaching include in the good category for product, process, and teachers personality.
\end{abstract}

Keywords: competency, physics teacher, six level of INQF

How to Cite: Jhoni, M. (2017). Studi ketercapaian KKNI guru fisika dan refleksinya dalam pembelajaran berbasis creative skill. Jurnal Pendidikan Matematika dan Sains, 5(1). doi:http://dx.doi.org/10.21831/jpms.v5i1.13539

Permalink/DOI: DOI: http://dx.doi.org/10.21831/jpms.v5i1.13539 


\section{PENDAHULUAN}

Perkembangan zaman dan era modernisasi menuntut adanya sumber daya manusia yang berkualitas serta mampu bersaing dalam dunia kerja. Proses pendidikan yang berkualitas menjadi salah satu kunci dalam mewujudkan terbentuknya SDM yang berkualitas tersebut. Dengan demikian diperlukan suatu standar kualifikasi nasional yang menjadi ukuran bagi kualitas output proses pendidikan, salah satunya yaitu Kerangka Kualifikasi Nasional Indonesia (KKNI). KKNI adalah kerangka penjenjangan kualifikasi kompetensi yang dapat menyan-dingkan, menyetarakan, dan mengintegrasikan antara bidang pendidikan dan bidang pelatihan kerja serta pengalaman kerja, dalam rangka memberi pengakuan kompetensi kerja, sesuai dengan struktur pekerjaan di berbagai sektor (Dirjen Dikti, 2010, p.8).

Kerangka kualifikasi tidak hanya dikenal di Indonesia. Menurut Wijeyaratne (2012, p.1), Departemen Pendidikan Tinggi Srilanka mende-finisikan Qualifications Framework (QF) adalah suatu kerangka kerja baru yang bertujuan untuk meningkatkan kualitas pendidikan tinggi dan pelatihan melalui pengakuan dan akreditasi kualifikasi yang ditawarkan oleh lembaga yang berbeda. Pernyataan tersebut sebagaimana juga dijelaskan dari The European Centre for the Development of Vocational Training sebagai national qualifications frameworks (NQFs) have, over a short period of time, developed into key instruments influencing national education, training and qualifications systems (Cedefop, 2010, p.5). Menurut Masia (2010, p.1), Menteri Pendidikan Tinggi Italia telah melakukan penandatangan dan memutuskan untuk mengembangkan kerangka kualifikasi untuk Pendidikan Tinggi Eropa. Kerangka Kualifikasi Pendidikan Tinggi Eropa bertujuan untuk memfasilitasi pemahaman yang benar dan komparabilitas kualifikasi di Sistem Pendidikan Tinggi masingmasing negara. Tujuan selanjutnya dari kerangka kualifikasi adalah untuk menawarkan gambaran yang komprehensif tentang ajaran Eropa dan menawarkan belajar, ditargetkan pada maha-siswa yang datang dari seluruh dunia. Setiap negara berkomitmen untuk mengumpulkan Kerangka Kualifikasi Nasional (National Qualification Framework, NQF) yang kompatibel dengan Kerangka Kualifikasi untuk Pendidikan Tinggi Eropa.
Kerangka Kualifikasi Eropa untuk belajar sepanjang hayat terdiri dari delapan tingkat yang didefinisikan oleh satu set deskriptor menunjukkan hasil belajar yang dinilai berdasarkan tiga kriteria yaitu pengetahuan, keterampilan dan kompetensi (Kaminskienè, 2011, p.5). Dalam konteks $E Q F$, pengetahuan digambarkan sebagai teoritis dan faktual. Keterampilan digambarkan sebagai kognitif (melibatkan penggunaan logis, berpikir intuitif dan kreatif), dan praktis (meli-batkan ketangkasan manual dan penggunaan metode, bahan, alat, dan instrumen).

KKNI menjadi acuan dalam pengemasan Standar Kerangka Kualifikasi Nasional Indonesia (SKKNI) ke tingkat atau jenjang kualifikasi. KKNI diposisikan sebagai penyetara capaian pembelajaran yang diperoleh melalui pendidikan formal, informal, dan nonformal dengan kom-petensi kerja yang dicapai melalui pelatihan di luar ranah Kemdikbud, pengalaman kerja atau jenjang karir di tempat kerja, sedangkan capaian pembelajaran (learning outcomes) adalah kemampuan yang diperoleh melalui internalisasi pengetahuan, sikap, ketrampilan, kompetensi, dan akumulasi pengalaman kerja (Dirjen Dikti, 2010, p.17-18).

Umumnya KKNI disusun berjenjang dari terendah sampai tertinggi (level satu sampai level Sembilan) berdasarkan kemampuan bekerja, penguasaan pengetahuan yang dicapai melalui pendidikan atau keterampilan yang diperoleh melalui pelatihan. EQF menyepadankan jenjang kualifikasi dengan jenjang pendidikan atau pela-tihan, bahkan dengan gelar yang disandangnya. Konsep pembelajaran sepanjang hayat nampak kuat mendasari pengembangan EQF (Marko-witsch, 2008, p.46-49).

Jenjang KKNI level enam merupakan jenjang mahasiswa sarjana S1 yang sedang melaksanakan proses capaian pembelajaran (learning outcomes) di sebuah universitas. KKNI memfasilitasi perpindahan bagi mahasiswa untuk melanjutkan studi atau pindah ke pasar tenaga kerja (Higher Education Comprises HBO, 2008, p.3). KKNI level tujuh adalah profesi. Guru fisika merupakan profesi guru sebagai output/outcome dari kurikulum selama ini. Pengaruh globalisasi membuat jenjang jevel tujuh menyumbang angka pengangguran lulusan setiap tahunnya menga-lami peningkatan kirakira $20 \%$. Hal ini meng-indikasikan bahwa daya serap tenaga kerja lulus-an sarjana masih perlu ditingkatkan (BPS, 2010, p.2). 
Berdasarkan hasil Uji Kompetensi Guru (UKG) SMA bidang fisika pada bulan Februari 2012 diperoleh fakta nilai rerata para guru seSumatera Selatan adalah 37,16, nilai yang tertinggi adalah 69,0 , dan nilai yang terendah adalah 17,0 . Urutan nilai rata-rata tertinggi guru fisika se-Indonesia yang tertinggi adalah DIY dengan rata-rata 51,55, kemudian Jawa Tengah dengan rata-rata 47,81, dan Bangka Belitung 47,61. Melihat kondisi seperti ini, sudah semestinya pemerintah dan stakeholder pendidikan yang ada mulai menekan alarm bahaya dan berusaha meningkatkan mutu kompetensi para guru di Indonesia guna mencari solusi atas permasalahan ini. Salah satu penyebabnya adalah tidak adanya kesesuaian antara standar kuali-fikasi learning outcomes KKNI level enam yang terdapat pada dokumen kurikulum Program Studi dengan stakeholder dan pengguna lulusan.

Kata kurikulum telah ada lama ada dan banyak interpretasi dari para tokoh pendidikan. Interpretasi tersebut bergantung dari filsafat yang dianutnya. Menurut Oliva (1992, p.6) tentang kurikulum dijelaskan bahwa: Curriculum is that which is taught in school.Curriculum is a set of subjects. Curriculum is content. Curriculum is a program of studies.Curriculum is a set of mate-rials. Curriculum is a sequence of courses. Curriculum is a set of performance objectives. Curriculum is a cource of study. Curriculum is everything that goes on within the school, including extraclass activities, guidance, and interpersonal relationships. Curriculum is that which is taught both inside and outside of school directed by school. Curriculum is everything that is planned by school personnel. Curriculum is a series of experience undergone by learner in school.

Secara umum kurikulum dapat dipandang sebagai persiapan sebelum pelaksanaan pembelajaran. Banyak definisi kurikulum oleh para ahli, tetapi yang terpenting adalah esensi dari kuri-kulum yaitu isi kurikulum. Isi kurikulum merupakan susunan, bahan kajian, dan pelajaran untuk mencapai tujuan penyelenggaraan satuan pendidikan yang bersangkutan dalam rangka upaya pencapaian tujuan pendidikan nasional. Null (2011, p.1) menyatakan bahwa kurikulum adalah jantung pendidikan. Alasannya adalah: (1) kurikulum merupakan sesuatu yang akan diajarkan, dan (2) kurikulum merupakan kombinasi pemikiran, perbuatan, dan tujuan. Pendapat lain oleh Allen \& Unwin (1993, p.8) menyatakan bahwa kurikulum merupakan sebuah perencanaan yang dibuat untuk memandu pembelajaran di perguruan tinggi, yang biasanya diwakili oleh beberapa dokumen yang tersedia dari semua level secara umum, dan aktualisasi dari perencanaan pembelajaran di kelas atau di laboratorium, sebagai pengalaman oleh pembelajar dan direkam dengan pengamatan, pengalamanpengalaman ini ditempatkan dalam lingkungan pembelajaran yang mana mempengaruhi apa yang diajarkan.

Pendapat lainnya seperti dikemukan Bharvad (2010, p.74) yang mendefinisikan kuri-kulum sebagai jumlah total semua pengalaman yang harus diberikan kepada mahasiswa dan ditransferkan oleh dosen atau sebagai pem-belajaran yang direncanakan dan dipandu penga-laman yang dirumuskan melalui rekonstruksi yang sistematis dari pengetahuan. Kurikulum yang dikembangkan harus difilter melalui teknik evaluasi. Kurikulum yang baik adalah yang penting bagi perkembangan anak, sistem, dan akhirnya untuk pembangunan nasional.

Smith (2013, p.1) seorang yang ahli kurikulum dan pembelajaran menyatakan bahwa tanpa kekuatan kurikulum maka pembelajaran menjadi lemah dan hilang. Kurikulum mengarahkan proses pembelajaran dan tanpa kurikulum maka tidak ada pembelajaran. Kurikulum dan pembe-lajaran sangat berhubungan erat. Teori tersebut didasarkan pada penelitian dan pengalaman seorang guru atau dosen.

Definisi kurikulum untuk perguruan tinggi sebagaimana yang dinyatakan Light, et.al (2009, p.75) yaitu bahwa kurikulum lebih dari sekedar komponen-komponen pengetahuannya. Penaf-siran yang luas dan tepat, kurikulum mencakup waktu pekerjaan mahasiswa dengan menawarkan sebelumnya. Urutan dan pemberian elemen-elemen pengetahuan dalam kurikulum mencer-minkan kesan tersendiri dari tokoh pendidikan karena untuk perhitungan perbuatan sungguh-sungguh dari pengetahuan.

Berdasarkan pendapat-pendapat tersebut, kurikulum merupakan apa yang diajarkan di sekolah. Kurikulum merupakan susunan mata pelajaran. Kurikulum merupakan isi atau materi pelajaran. Kurikulum merupakan program studi. Kurikulum merupakan susunan materi atau bahan ajar. Kurikulum merupakan rangkaian pelatihan. Kurikulum merupakan prestasi yang hendak dicapai. Kurikulum merupakan pelatihan dari pelajaran. Kurikulum merupakan segala hal 
yang diberikan oleh sekolah, meliputi aktifitas tambahan kelas, bimbingan, dan hubungan secara interpersonal. Kurikulum merupakan segala hal yang direncanakan oleh sekolah secara mandiri. Kurikulum merupakan rangkaian pengalaman yang dilalui oleh pembelajaran di sekolah.

Para guru di negara-negara maju seperti Amerika, Australia, Rusia, dan negara-negara di benua Eropa lainnya, telah memenuhi standar kualifikasi nasional. Artinya seluruh guru di negara-negara tersebut memiliki standar minimal kualifikasi sebagai guru yang berlaku secara nasional. Kompetensi lulusan guru dari univer-sitas manapun di negara tersebut, sudah tidak diragukan lagi. Sebab Kerangka Kerja Kuali-fikasi (Qualification Frameworks) yang telah tersistem mampu mensinergikan kualifikasi sekolah, vokasi, dan universitas menjadi satu sistem nasional.

Kurikulum 2013 juga telah memuat standar kualifikasi KKNI level enam yang dimiliki oleh guru yang bercirikan Student Active Learning (SAL) melalui proses pembelajaran langsung dan tidak langsung agar siswa memiliki kompetensi spiritual, sosial, pengetahuan, dan keterampilan. Dengan demikian, kesiapan guru fisika dalam menyongsong dunia kerja yaitu dunia pendidikan menjadi tuntutan yang tidak bisa ditawar-tawar lagi. Undang-Undang Nomor 14 Tahun 2005 tentang Guru dan Dosen mengamanatkan bahwa profesi guru merupakan bidang pekerjaan khusus yang dilaksanakan berdasarkan standar kompetensi sesuai bidang tugasnya dan pelaksanaan pengembangan keprofesian berkelanjutan sepanjang hayat (Presiden, 2005, p.3)

Fenomena kualitas guru tersebut salah satunya disebabkan oleh faktor lulusan pendidikan perguruan tinggi di Indonesia yang masih belum mengimplementasikan kompetensi penca-paian pembelajaran (Learning Outcomes/LO) yang berbasis KKNI level enam atau Indonesian Qualification Framework (IQF) level enam karena selama ini masih menggunakan kurikulum berbasis kompetensi (KBK) sesuai dengan PP No. 17 tahun 2010 pasal 97 dan Keputusan Menteri Pendidikan Nasional No. 232/U/2000 tentang pedoman penyusunan kurikulum penilaian hasil belajar mahasiswa dan belum berbasis pencapaian kompetensi standar yang dimiliki lulusan, sehingga dengan ditetapkannya Undang-Undang (UU) Nomor 12 Tahun 2012 Pasal 29 ayat (1), (2), dan (3) dan Peraturan Presiden Nomor 8 Tahun 2012 pada kurikulum dan pengelolaannya di setiap program studi perguruan tinggi, yang pada awalnya mengacu pada pencapaian kompetensi menjadi mengacu pada capaian pembelajaran (learning outcomes) KKNI. Hasil penelitian Fuady \& Prasetyo (2015) menunjukkan bahwa kesesuaian perencanaan dan pencapaian kemampuan calon guru terhadap KKNI masih berada pada kategori cukup. Hal ini menunjukkan bahwa masih perlunya pengembangan berbagai kompetensi untuk meningkatkan kualitas guru.

Menurut Bhargava (2010, p.77) kompetensi adalah karakteristik yang spesifik dan dapat didemonstrasikan atau atribut yang dibutuhkan untuk mengajar dengan profesional sehingga menciptakan lingkungan pembelajaran yang menyenangkan. Kompetensi dasar yang harus dimiliki guru untuk meningkatkan efektivitas pendidikan dan proses pembelajaran yang berkualitas adalah kompetensi organisasional, kompetensi instruksional, kompetensi pedagogik, kompe-tensi psikologi, kompetensi evaluatif, kompetensi sebagai penasehat, kompetensi untuk mengem-bangkan profesionalitas secara berkelanjutan, dan kompetensi untuk meneliti di bidang pendidikan (Marinkovic, 2011, p.6).

Menurut Atav (2010, p.38), kompetensi guru secara umum dapat didefinisikan sebagai pengetahuan profesional, keterampilan, dan sikap yang dibutuhkan untuk melaksanakan tugas mengajar secara profesional. Secara khusus dijelaskan bahwa selain tiga kemampuan tersebut, guru harus mempunyai kompetensi menggunakan peralatan laboratorium sehingga mampu mem-bimbing siswa untuk melakukan eksperimen.

Berdasarkan penjelasan tersebut dapat disimpulkan bahwa kompetensi merupakan kemampuan seseorang yang meliputi pengetahuan, keterampilan, dan sikap yang dapat diwujudkan dalam hasil kerja nyata yang bermanfaat bagi diri dan lingkungannya.

Konferensi di Berlin tahun 2003 menunjukan bahwa menteri bertanggung jawab atas pendidikan tinggi yang diselenggarakan. Para menteri menyatakan sepakat penandatangan untuk menyusun Kerangka Kualifikasi Eropa atau Framework for Qualifications in the European Higher Education Area (QFE-HEA) dan berkomitmen untuk mengembangkan kualifikasi nasional kerangka kerja yang akan sesuai dengan kerangka Eropa (Federal Ministry of Education and Research Republic of Germany, 2008, p.3). Bohlinger (2008, p.1) menyatakan 
bahwa kerangka kualifikasi ini sebagai mesin inovasi. Negara-negara yang memperkenalkan kerangka kualifikasi adalah negara yang sedang membuat sistem pendidikan nasional di negara mereka yang lebih transparan, lebih inovasiefektif dan lebih kompetitif. Kerangka kualifikasi juga bertujuan untuk meningkatkan kecocokan antara sistem pendidikan dan pasar tenaga kerja. Dengan demikian, kerangka kerja kualifikasi dipandang sebagai mesin inovasi yaitu titik yang memperkenalkan mereka untuk mempromosikan sejumlah fundamental dari reformasi jangka panjang.

Keterkaitan antara KKNI dengan beberapa unsur keterampilan-keterampilan yang mesti dimiliki guru adalah di dalam KKNI ada karakteristik unsur berbagai keterampilan (skill) yang mesti dimiliki para guru dalam setiap jenjang. Keterampilan-keterampilan (skills) tersebut diantaranya adalah creative skill, life skill, tech-nology skill, dan lain-lain.

Kreativitas merupakan salah satu keteram-pilan (skill) yang mampu menghasilkan produk atau unjuk kerja guna menjadikan proses pembelajaran menjadi lebih baik, bermutu, dan dapat meningkatkan minat belajar siswa karena dalam pembelajaran fisika terdapat materimateri yang bersifat abstrak, sehingga guru dituntut agar kreatif dalam mengkonkretkan materi abstrak tersebut. Salah satu contohnya adalah materi gerak jatuh. Diharapkan siswa dapat terbantu mengkonkretkan materi ini melalui alat peraga berupa pesawat atwood atau sensor gerak jatuh bebas yang dibuat oleh guru sehingga loncatan berpikir siswa tidak menimbulkan miskonsepsi dalam proses perceptual awarness dan concep-tual understanding.

Menurut Munandar (2004, p.35) bahwa biasanya seseorang kreatif selalu ingin tahu, memiliki minat yang luas, biasanya cukup mandiri dan memiliki rasa percaya diri, mereka lebih berani mengambil resiko (tetapi dengan perhitungan), berani dalam pendirian/keyakinan, rasa ingin tahu, mandiri dalam berpikir dan mempertimbangkan, bersibuk diri terus menerus dengan kerjanya, intuitif, ulet, tidak bersedia menerima pendapat dari otoritas begitu saja. Hal ini juga dipertegas oleh Rhodes (Isaken, et al, 2003, p.149) menyimpulkan bahwa pada umumnya kreativitas dirumuskan dalam istilah "four P's of creativity: Person, Process, Press, and Product". Keempatnya saling berkaitan. Pribadi kreatif yang melibatkan dalam proses kreatif dan dengan dukungan dan dorongan dari lingkungan menghasilkan produk kreatif, lalu produk kreatif ini juga dinyatakan oleh Rabari (2011, p. 234) bahwa: it is believed, will cultivate skilled scientists and engineers needed to create tomorrow's innovations. But the real essence of creativity goes beyond generating new ideas and products, as it is also recognized to enhance learning in a more economical way. Makna dari pendapat Rabari memiliki kesamaan pendapat yang dikemukakan oleh Afrizon, et al (2012, p.8) bahwa kreatif itu berpikir dan melakukan sesuatu untuk menghasilkan cara atau hasil baru dari sesuatu yang telah dimiliki.

Berbeda dengan beberapa pakar tersebut, Tan (2009, p.15) juga menambahkan bahwa kreativitas adalah sebuah potensi dasar yang nilainya bertambah pada suatu saat, peran dari pendidikan untuk merawat dan memupuk kreativitas sangat diperlukan.

Mengacu pada beberapa pendapat ahli tersebut, maka kreativitas seorang guru fisika SMA hendaknya memiliki tiga dimensi yaitu dimensi kreativitas dalam dirinya dengan indikator memiliki rasa ingin tahu, memiliki minat yang luas, memiliki percaya diri, memiliki dorongan dari lingkungan pendidikan untuk kreatif misalnya siswa, guru lain, kepala sekolah, fasilitas yang memadai. Dimensi berikutnya adalah dimensi proses kreativitas artinya guru yang kreatif adalah guru yang memiliki pola pikir divergen dalam mencari jawaban atau solusi atas suatu masalah. Cara berpikir divergen maksud-nya adalah kemampuan guru untuk mencari berbagai alternatif jawaban terhadap suatu persoalan, sedangkan konvergen adalah cara berpikir guru dalam memikirkan sesuatu dengan berpandangan hanya ada satu jawaban benar. Dimensi terakhir adalah dimensi produk kreativitas. Indikator dari dimensi ini adalah guru dapat mengembangkan dan memodifikasi alat peraga dalam pembelajaran, guru dapat mengembang-kan media pembelajaran fisika sehingga men-jadikan materi pembelajaran menjadi konkrit, mudah, menarik dan komunikatif, guru dapat menggunakan metode pembelajaran yang tepat dan sesuai dengan materi yang akan diberikan, guru dapat memanfaatkan lingkungan sekolah sebagai sumber belajar, guru dapat meman-faatkan potensi lokal di sekitar sekolah sebagai sumber belajar, dan guru dapat memanfaatkan pengalaman siswa sebagai sumber belajar.

Keberhasilan proses pembelajaran tidak terlepas juga dari bentuk usaha guru dalam 
merancang pembelajaran dan mengembangkan kreativitas siswa. Para guru juga harus mampu memberikan solusi terhadap rendahnya prestasi belajar. Oleh karena itu, guru juga dituntut untuk menjadi guru yang solutif dan kreatif, misalnya dengan adanya pemberian motivasi yang membuat siswa senang mengikuti pelajaran sehingga mampu meningkatkan prestasi pembelajaran.

Kunci untuk membangun dan memupuk kreativitas terletak di tangan guru. Pembelajaran yang kreatif dapat dilihat dari dua sisi yaitu mengajar secara kreatif (creative teaching) dan mengajar untuk kreativitas (teaching for creativity). Mengajar secara kreatif mengambarkan bagaimana guru dapat menggunakan pendekatan-pendekatan imajinatif sehingga kegiatan pembe-lajaran dapat semakin lebih menarik, membang-kitkan minat, dan efektif.

Permasalahan terkait rendahnya kreativitas guru dapat memunculkan opini pada siswa bahwa pembelajaran fisika merupakan materi pembe-lajaran yang sulit dan membosankan. Kreativitas guru sangat dibutuhkan dalam meningkatkan minat dan motivasi siswa serta kreatif dalam menggunakan metode pembelajaran yang menarik. Kreativitas merupakan hal yang penting dimi-liki guru dan melihat permasalahan dalam proses pembelajaran fisika di SMA.

Berangkat dari semua permasalahan tersebut maka penelitian ini akan fokus pada studi ketercapaian KKNI level enam guru fisika SMA lulusan Universitas Sriwijaya dan kemampuannya dalam mengembangkan pembelajaran fisika berbasis creative skill. Dengan demikian tujuan dari penelitian ini adalah untuk mengetahui: (1) ketercapaian kompetensi guru fisika Prodi Pendidikan Fisika UNSRI terhadap KKNI dan (2) refleksinya dalam pembelajaran fisika berbasis creative skill. Draft KKNI level enam yang dapat menjadi pedoman khususnya bagi penyelenggaraan strata satu (sarjana) Program Studi Pendidikan Fisika telah disusun dan telah divalidasi oleh beberapa pakar ahli yang selanjutnya mencari permasalahan yang terjadi di lapangan, dan hasilnya dapat disarankan kepada perguruan tinggi guna perbaikan kompetensi guru fisika lulusan Universitas Sriwijaya khusus-nya dan Universitas lainnya agar dapat menjadi lebih baik lagi.

\section{METODE}

Jenis Penelitian Penelitian adalah survei yang menggunakan meode campuran, deskriptif kualitatif dan kuantitatif. Pendekatan kuantitatif untuk menganalisis lembar angket, observasi dan dokumentasi sedangkan pendekatan kualitatif untuk menganalisis data hasil wawancara. Waktu penelitian ini sekitar lima bulan yaitu Januari-Mei 2014. Tempat penelitian yaitu SMA/SMK/ MA negeri dan swasta yang ada di Kota Palembang dan sekitarnya dalam lingkup wilayah Sumatera Selatan.

Populasi dalam penelitian ini adalah seluruh guru fisika SMA/SMK/MA negeri dan swasta yang merupakan lulusan Program Studi Pendidikan Fisika Universitas Sriwijaya yang ada di kota Palembang dan sekitarnya dengan batasan lima tahun dari kelulusannya. Sampel penelitian diambil sebanyak 12 guru fisika dengan cara purposive sampling, teknik sampling dengan pertimbangan tertentu (Subali, 2010, p.9) yaitu dengan mempertimbangkan keadaan guru fisika untuk menjadi sampel penelitian ini. Untuk mendapatkan data yang valid tentang gambaran ketercapaian KKNI level enam dan kreativitas dalam pembelajaran guru fisika yang kelulusannya lima tahun dari Prodi Pendidikan Fisika FKIP Universitas Sriwijaya dilakukan trianggulasi data antara jawaban yang diberikan oleh 12 guru fisika, 12 guru senior fisika/kepala sekolah, dan 364 siswa yang pernah atau sedang diajar oleh guru fisika yang bersangkutan.

Prosedur penelitian dilakukan dengan memberikan lembar angket, melakukan observasi secara langsung dalam pembelajaran, dokumentasi, dan wawancara. Lembar angket diberikan kepada guru yang bersangkutan (diri sendiri) kemudian data yang diperoleh ditrianggulasikan terhadap lembar angket yang diisi oleh guru senior fisika dan siswa. Observasi dilakukan sebanyak dua kali pertemuan. Dokumentasi dila-kukan sebagai penilaian data pendukung berupa RPP, LKPD, sertifikat pelatihan, workshop, dll. Wawancara juga dilakukan untuk memperoleh informasi kompetensi yang dimiliki guru.

Data yang dikumpulkan berupa data ketercapaian KKNI level enam dan kreativitas guru fisika SMA/SMK/MA lulusan Universitas Sriwijaya. Instrumen pengumpulan data yang digunakan adalah lembar angket, lembar observasi, lembar review dokumen, dan lembar panduan wawancara. Lembar angket digunakan untuk memperoleh data ketercapaian KKNI dan kreativitas guru fisika, observasi langsung dilakukan untuk memperoleh data.

Teknik analisis data dengan analisis deskriptif kuantitatif yaitu dengan menentukan tingkat kecenderungan dengan kategorisasi. 
Tabel 1. Kriteria Penilaian Masing-masing Variabel

\begin{tabular}{cc}
\hline Rentang Skor & Kriteria \\
\hline $\mathrm{X}>\mathrm{Xi}+1,8 \mathrm{SBi}$ & Sangat baik \\
$\mathrm{Xi}+0,6 \mathrm{SBi}<\mathrm{X} \leq \mathrm{Xi}+1,8 \mathrm{SBi}$ & Baik \\
$\mathrm{Xi}-0,6 \mathrm{SBi}<\mathrm{X} \leq \mathrm{Xi}+0,6 \mathrm{SBi}$ & Cukup \\
$\mathrm{Xi}-1,8 \mathrm{SBi}<\mathrm{X} \leq \mathrm{Mi}-0,6 \mathrm{SBi}$ & Kurang \\
$\mathrm{X} \leq \mathrm{Xi}-1,5 \mathrm{SBi}$ & Sangat Kurang \\
\hline
\end{tabular}

Widoyoko (2009, p.238)

\section{HASIL DAN PEMBAHASAN}

Sampel pada penelitian adalah 12 guru lulusan lima tahun terakhir dari kelulusannya pada program studi pendidikan fisika FKIP Universitas Sriwijaya yang mengajar di SMA/ MA/SMK negeri dan swasta di kota Palembang dan sekitarnya. Penelitian ini melibatkan 12 guru fisika yang kelulusannya di bawah lima tahun (2010-2014), 12 Guru Senior Fisika, dan 364 siswa sebagai data untuk mengecek kebenar-an/keabsahan data yang diberikan oleh guru fisika yang menjadi sampel penelitian. Pada penelitian ini terdapat dua variabel yang akan diukur yaitu ketercapaian Learning Outcomes KKNI level enam guru fisika dan reflektif terhadap guru dalam pembelajaran fisika SMA berbasis creative skill. Masingmasing variabel dijelaskan sebagai berikut.

\section{Ketercapaian KKNI Deskriptor Pertama}

Ketercapaian Learning Outcomes KKNI level enam guru fisika SMA berdasarkan deskrip-tor pertama ini adalah kemampuan dalam memanfaatkan IPTEKS di bidang keahliannya dan kemampuan beradaptasi terhadap situasi yang dihadapi dalam penyelesaian masalah yang meliputi tiga kompetensi yaitu kemampuan memanfaatkan ICT (Information and Communication Technology) dalam pembelajaran fisika, kemam-puan dalam menggunakan peralatan laboratorium pembelajaran fisika, dan kemampuan dalam menciptakan alat sederhana untuk kelancaran pembelajaran fisika.

Penilaian ketercapaian deskriptor ini dilakukan dengan menggunakan lembar angket yang diisi oleh 12 guru fisika yang bersangkutan kemudian ditrianggulasikan terhadap angket. Data ketercapaian KKNI level enam deskriptor pertama disajikan pada Tabel 2 berikut.

Tabel 2. Data Ketercapaian Kompetensi pada Deskriptor Pertama

\begin{tabular}{|c|c|c|c|c|c|c|c|c|}
\hline & \multicolumn{2}{|c|}{ Diri Sendiri } & \multicolumn{2}{|c|}{$\begin{array}{c}\text { Guru } \\
\text { Senior }\end{array}$} & \multicolumn{2}{|c|}{ Siswa } & \multicolumn{2}{|c|}{ Observasi } \\
\hline & $\mathrm{F}$ & $\%$ & $\mathrm{~F}$ & $\%$ & $\mathrm{~F}$ & $\%$ & $\mathrm{~F}$ & $\%$ \\
\hline Sgt. Baik & 0 & 0 & 0 & 0 & 0 & 0 & 1 & 8,33 \\
\hline Baik & 10 & 83,3 & 9 & 75 & 9 & 75 & 7 & 58,3 \\
\hline Cukup & 2 & 16,6 & 3 & 25 & 2 & 167 & 3 & 25 \\
\hline Kurang & 0 & 0 & 0 & 0 & 1 & 8,33 & 1 & 8,33 \\
\hline $\begin{array}{l}\text { Sgt. } \\
\text { Kurang }\end{array}$ & 0 & 0 & 0 & 0 & 0 & 0 & 0 & 0 \\
\hline Rerata & & & & & & ik & Bai & \\
\hline
\end{tabular}

Tabel 2 menunjukkan persentase dan rata-rata ketercapaian kompetensi guru fisika berdasarkan KKNI level enam pada deskriptor pertama. Meskipun ada beberapa kompetensi dengan kriteria cukup tetapi secara keseluruhan persentase rerata pada deskriptor pertama dalam kriteria baik. Tabel 2 tersebut juga dapat disajikan dalam bentuk gambar diagram berikut.

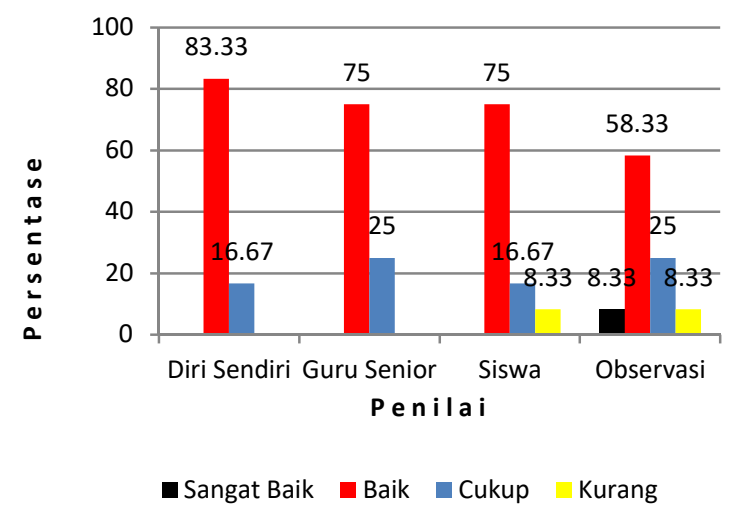

Gambar 1. Diagram Ketercapaian KKNI Level Enam Deskriptor Pertama Guru Fisika Lulusan Universitas Sriwijaya

Gambar 2 menunjukkan tingkat ketercapaian KKNI level enam pada deskriptor pertama yang ditinjau dari tiga kompetensi yaitu kemampuan memanfaatkan ICT dalam pembelajaran fisika, kemampuan dalam menggunakan peralatan labo-ratorium/kit pembelajaran, dan kemampuan dalam menciptakan alat sederhana untuk kelancaran pembelajaran fisika.

Persentase penilaian ketercapaian yang paling tinggi adalah penilaian dari diri sendiri dengan kriteria baik sebesar $83,33 \%$ dan persentase ketercapaian paling rendah adalah penilaian berdasarkan observasi kriteria kurang sebesar $8,33 \%$. Penilaian ketercapaian kriteria kurang ini berdasarkan analisis data-data kompetensi guru dalam menggunakan peralatan laboratorium/kit pembelajaran fisika dan menciptakan alat sederhana untuk pembelajaran.

Kompetensi guru dalam menggunakan peralatan laboratorium/kit pembelajaran fisika masih tergolong cukup Selain itu, kompetensi 
guru baru lulusan Universitas Sriwijaya dalam menciptakan alat sederhana dalam pembelajaran fisika masih tergolong cukup berdasarkan lembar angket dan kurang berdasarkan observasi.

Dari penjelasan di atas, dapat disimpulkan bahwa sebagain besar guru Prodi Pendidikan Fisika, lulusan Universitas Sriwijaya masih dikatakan lemah dalam menggunakan peralatan laboratorium/kit pembelajaran fisika dengan baik serta belum mampu menciptakan alat peraga sederhana. Selain itu, kemampuan guru baru fisika lulusan Universitas Sriwijaya dalam memanfaatkan ICT pembelajaran fisika secara umum sudah baik. Dengan demikian, kelemahan dapat dijadikan bahan evaluasi guna perbaikan kurikulum prodi.

\section{Ketercapaian KKNI pada Deskriptor Kedua}

Deskriptor kedua menyatakan kemampuan menguasai konsep teoritis bidang pengetahuan secara umum dan konsep teoritis bagian khusus bidang pengetahuan tersebut secara mendalam serta mampu memformulasikan penyelesaian masalah prosedural. Kompetensi yang dinilai adalah kompetensi professional dan kompetensi pedagogic. Data yang dihasilkan dapat disajikan pada Tabel 3 berikut.

Tabel 3. Data Ketercapaian Kompetensi Berdasarkan KKNI Level Enam Deskriptor Kedua

\begin{tabular}{|c|c|c|c|c|c|c|c|c|}
\hline \multirow{3}{*}{ Kriteria } & \multicolumn{8}{|c|}{ Penilai } \\
\hline & \multicolumn{2}{|c|}{ Diri Sendiri } & \multicolumn{2}{|c|}{$\begin{array}{l}\text { Guru } \\
\text { Senior }\end{array}$} & \multicolumn{2}{|c|}{ Siswa } & \multicolumn{2}{|c|}{$\begin{array}{c}\text { Obser- } \\
\text { vasi }\end{array}$} \\
\hline & $\mathrm{F}$ & $\%$ & $\mathrm{~F}$ & $\%$ & $\mathrm{~F}$ & $\%$ & F & $\%$ \\
\hline $\begin{array}{l}\text { Sangat } \\
\text { Baik }\end{array}$ & 2 & 16,7 & 4 & 33,3 & 5 & 41,6 & 5 & 41,6 \\
\hline Baik & 10 & 83,3 & 8 & 66,7 & 7 & 58,3 & 4 & 33,3 \\
\hline Cukup & 0 & 0 & 0 & 0 & 0 & 0 & 2 & 16,6 \\
\hline Kurang & 0 & 0 & 0 & 0 & 0 & 0 & 1 & 8,33 \\
\hline $\begin{array}{l}\text { Sangat } \\
\text { Kurang }\end{array}$ & 0 & 0 & 0 & 0 & 0 & 0 & 0 & 0 \\
\hline Rerata & & & & aik & & & & aik \\
\hline
\end{tabular}

Tabel 3 menunjukkan persentase dan ratarata ketercapaian KKNI level enam pada deskriptor kedua kompetensi guru fisika berdasarkan penilaian diri sendiri (guru yang bersangkutan), guru senior fisika dan siswa, serta berdasarkan observasi yang dilakukan langsung dalam proses pembelajaran guru.

Keseluruhan kompetensi pada deskriptor kedua dapat dikatakan termasuk dalam kriteria baik. Data Tabel 3 juga dapat disajikan dalam bentuk diagram seperti pada Gambar 2. Gambar 2 menunjukkan bahwa persentase tingkat keter- capaian KKNI level enam deskriptor kedua ini yang paling tinggi adalah dengan kri-teria baik sebesar $83,33 \%$ berdasarkan penilaian diri sendiri, sedangkan tingkat ketercapaian paling rendah adalah kriteria kurang berdasarkan penilaian hasil observasi yaitu sebesar 8,33\%.

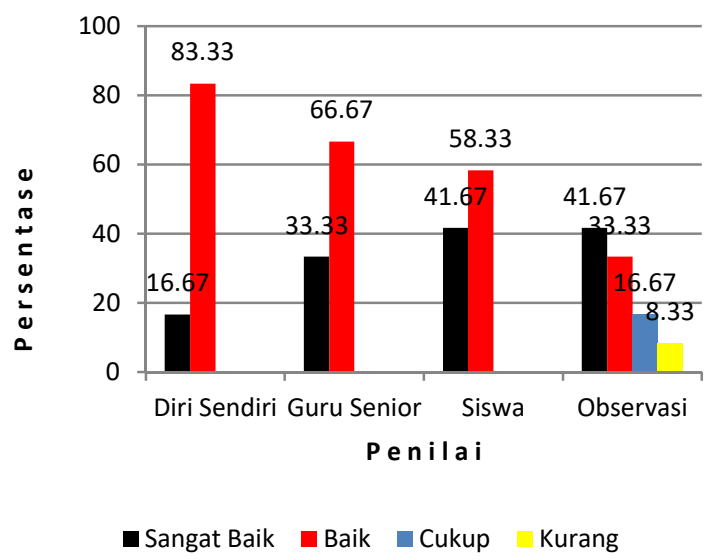

Gambar 2. Diagram Ketercapaian KKNI Level Enam Deskriptor Kedua Guru Fisika Lulusan Universitas Sriwijaya

Secara umum, berdasarkan analisis data aspek kompetensi-kompetensi di atas tingkat ketercapaian pada deskriptor kedua ini dalam kategori baik. Hal ini artinya bahwa guru fisika lulusan Universitas Sriwijaya sudah memiliki kemampuan penguasaan materi pembelajaran dan mengelola pembalajaran dengan baik.

\section{Ketercapaian KKNI pada Deskriptor Ketiga}

Deskriptor generik ketiga menjelaskan bahwa kemampuan mengambil keputusan strategis berdasarkan analisis informasi/data dan memberikan petunjuk dalam memilih berbagai alternatif solusi. Penilaian ketercapaian KKNI level enam deskriptor ketiga ini dilakukan dengan menggunakan lembar angket yang diisi oleh guru fisika yang bersangkutan, guru senior fisika, dan siswa, observasi dan dokumentasi. Berikut Tabel 4 yang menyajikan data ketercapaian KKNI level enam pada deskriptor ketiga.

Tabel 4. Data Ketercapaian Kompetensi Guru Fisika Berdasarkan KKNI Level Enam Pada Deskriptor Ketiga

\begin{tabular}{lcccccc}
\hline \multirow{2}{*}{ Kriteria } & \multicolumn{6}{c}{ Penilai } \\
\cline { 2 - 8 } & \multicolumn{2}{c}{ Diri Sendiri } & \multicolumn{2}{c}{ Guru Senior } & \multicolumn{2}{c}{ Siswa } \\
& F & $\%$ & F & $\%$ & F & $\%$ \\
\hline Sangat Baik & 1 & 8,33 & 2 & 16,7 & 2 & 16,7 \\
Baik & 11 & 91,7 & 10 & 83,3 & 8 & 66,7 \\
Cukup & 0 & 0 & 0 & 0 & 2 & 16,7 \\
Kurang & 0 & 0 & 0 & 0 & 0 & 0 \\
Sangat Kurang & 0 & 0 & 0 & 0 & 0 & 0 \\
\hline \multicolumn{1}{c}{ Rerata } & \multicolumn{2}{c}{ Baik } & \multicolumn{3}{c}{ Baik } \\
\hline
\end{tabular}


Tabel 4 menunjukkan persentase dan rata-rata ketercapaian kompetensi guru fisika berdasarkan KKNI level enam pada deskriptor ketiga yang termasuk dalam kriteria baik. Data Tabel 4 juga dapat disajikan dalam bentuk ambar diagram seperti pada Gambar 3. Gambar 3 menunjukkan rata-rata persentase ketercapaian KKNI level enam deskriptor ketiga berdasarkan penilaian diri sendiri, guru senior fisika, dan siswa. Penilaian ketercapaian yang paling tinggi adalah penilaian diri sendiri sebesar $91,67 \%$ dengan kriteria baik sedangkan penilaian ketercapaian yang paling rendah adalah penilaian siswa sebesar 16,67\% dengan kriteria cukup. Kriteria cukup ini berda-sarkan analisis data pada aspek kompetensi penguasaan metode penelitian pendidikan yang dimiliki guru atau dengan kata lain kelemahan lulusan Universitas Sriwijaya guru baru fisika pada deskriptor ini adalah pada penguasaan metode penelitian pendidikan. Kelemahan ini dapat dilihat pada data yang berdasarkan penilaian diri sendiri, guru senior, dan siswa dalam kategori cukup dan berdasarkan hasil dokumentasi juga dalam kategori cukup.

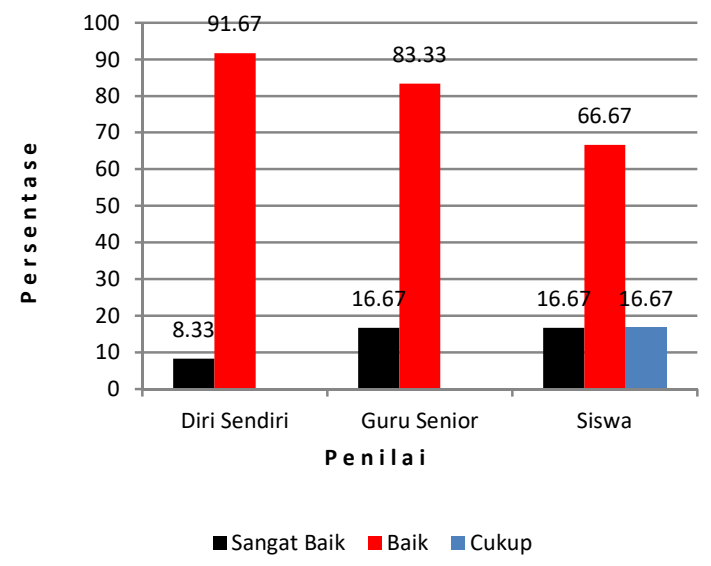

Gambar 3. Diagram Ketercapaian KKNI Level Enam Deskriptor Ketiga Guru Fisika Lulusan Universitas Sriwijaya

\section{Ketercapaian KKNI pada Deskriptor Keempat}

Pada deskriptor generik yang keempat ini berbunyi bahwa bertanggung jawab pada pekerjaan sendiri dan dapat diberi tanggung jawab atas pencapaian hasil kerja organisasi. Kompetensi guru berdasarkan KKNI level enam deskriptor keempat ini ditinjau dari tiga kompetensi yaitu kompetensi sebagai guru fisika, kompetensi kepribadian, dan kompetensi sosial. Penilaian ketercapaian deskriptor ini dilakukan dengan menggunakan lembar angket. Data tingkat ketercapaian yang dihasilkan dapat disajikan pada Tabel 5 . Tabel 5 menunjukkan persentase dan rata-rata ketercapaian kompetensi guru fisika berdasarkan KKNI level enam pada deskriptor keempat. Berdasarkan penilaian dari hasil lembar angket memiliki kriteria baik. Data dari Tabel 5 juga dapat disajikan dalam bentuk diagram seperti pada Gambar 4.

Tabel 5. Data Ketercapaian Kompetensi Guru Fisika berdasarkan KKNI Level Enam pada Deskriptor Keempat

\begin{tabular}{|c|c|c|c|c|c|c|}
\hline \multirow{3}{*}{ Kriteria } & \multicolumn{6}{|c|}{ Penilai } \\
\hline & \multicolumn{2}{|c|}{$\begin{array}{c}\text { Diri } \\
\text { Sendiri }\end{array}$} & \multicolumn{2}{|c|}{$\begin{array}{c}\text { Guru } \\
\text { Senior }\end{array}$} & \multicolumn{2}{|c|}{ Siswa } \\
\hline & $\mathrm{F}$ & $\%$ & $\mathrm{~F}$ & $\%$ & $\mathrm{~F}$ & $\%$ \\
\hline Sangat Baik & 3 & 25 & 3 & 25 & 4 & 33,3 \\
\hline Baik & 9 & 75 & 8 & 66,7 & 8 & 66,7 \\
\hline Cukup & 0 & 0 & 1 & 8,33 & 0 & 0 \\
\hline Kurang & 0 & 0 & 0 & 0 & 0 & 0 \\
\hline Sangat Kurang & 0 & 0 & 0 & 0 & 0 & 0 \\
\hline Rerata & \multicolumn{2}{|c|}{ Baik } & \multicolumn{2}{|c|}{ Baik } & \multicolumn{2}{|c|}{ Baik } \\
\hline
\end{tabular}

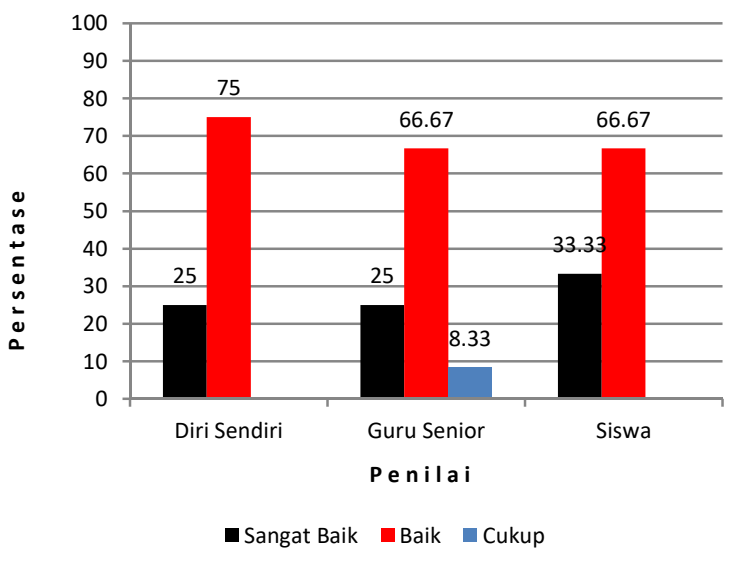

Gambar 4. Diagram Ketercapaian KKNI Level Enam Deskriptor keempat Guru Fisika Lulusan Universitas Sriwijaya.

Gambar 4 menunjukkan rata-rata persentase ketercapaian KKNI level enam deskriptor keempat berdasarkan penilaian diri sendiri, guru senior fisika, dan siswa. Penilaian ketercapaian yang paling tinggi adalah penilaian diri sendiri sebesar $75 \%$ dengan kriteria baik, sedangkan penilaian ketercapaian yang paling rendah adalah penilaian guru senior fisika sebesar 8,33\% dengan kriteria cukup.

Berdasarkan penjelasan ini dapat disimpulkan bahwa secara umum ketercapaian KKNI level enam guru baru fisika lulusan Universitas Sriwijaya memiliki kriteria cukup untuk deskriptor pertama, dan kriteria baik untuk deskriptor kedua, ketiga, dan keempat namun demikian 
tetap memiliki kelemahan dari segi kompetensi menggunakan peralatan laboratorium, menciptakan alat sederhana untuk pembelajaran fisika, kompetensi profesional, dan penguasaan metode penelitian.

\section{Refleksi Guru Fisika dalam Pembelajaran Fisika Berbasis Creative Skill}

Penilaian kreativitas guru yang kreatif ini terbagi menjadi tiga dimensi yaitu dimensi produk kreativitas guru, dimensi kepribadian, dan dimensi proses kreativitas guru fisika yang kreatif. Penilaian ini dilakukan dengan menggunakan lembar angket dan observasi. Lembar angket diisi oleh guru fisika yang bersangkutan kemudian ditrianggulasikan terhadap angket yang diisi oleh guru fisika senior atau kepala sekolah atau wakil kepala sekolah bidang kurikulum dan sejumlah siswa yang pernah di ajar oleh guru fisika yang bersangkutan. Observasi dilakukan sebanyak dua kali di dalam proses pembelajaran. Data yang dihasilkan secara umum dijelaskan di bawah ini.

\section{Dimensi Produk Kreativitas Guru}

Data berdasarkan lembar angket disajikan pada Tabel 6.

\section{Tabel 6. Data Dimensi Produk Guru}

\begin{tabular}{lccc}
\hline \multicolumn{1}{c}{ Hasil Analisis } & $\begin{array}{c}\text { Diri } \\
\text { Sendiri }\end{array}$ & $\begin{array}{c}\text { Guru } \\
\text { Senior }\end{array}$ & Siswa \\
\hline Rerata skor ideal (Xi) & 15 & 15 & 15 \\
Simpangan baku ideal & 3 & 3 & 3 \\
Skor maksimal ideal & 24 & 24 & 24 \\
Skor minimal ideal & 6 & 6 & 6 \\
Skor maksimal angket & 4 & 4 & 4 \\
Skor minimal angket & 1 & 1 & 1 \\
\hline Rerata skor aktual (X) & 16,75 & 16,58 & 16,79 \\
& (Cukup) & (Cukup) & (Cukup) \\
\hline
\end{tabular}

Point satu (rerata skor ideal) sampai dengan enam (skor minimal angket) terlihat nilainya sama tetapi rerata skor aktualnya berbeda, hal ini disebabkan karena jumlah butir angket yang diberikan responden itu berbeda-beda. Berikut kriterianya berdasarkan penilaian diri sendiri, guru senior fisika dan siswa sesuai Tabel 7.

Tabel 7. Kriteria Dimensi Produk Kreativitas Guru yang Kreatif

\begin{tabular}{lc}
\hline \multicolumn{1}{c}{ Interpretasi } & Rerata Skor \\
\hline Sangat Baik & $20,4<\mathrm{X}$ \\
Baik & $16,8<\mathrm{X} \leq 20,4$ \\
Cukup & $13,2<\mathrm{X} \leq 16,8$ \\
Kurang & $9,6<\mathrm{X} \leq 13,2$ \\
Sangat Kurang & $\mathrm{X} \leq 9,6$ \\
\hline
\end{tabular}

Data berdasarkan hasil observasi dilakukan sebanyak dua kali pada masing-masing pembelajaran yang diselenggarakan oleh guru fisika. Secara umum data-data tersebut sesuai Tabel 8.

Tabel 8. Data Hasil Observasi Dimensi Produk Kreativitas Guru Fisika

\begin{tabular}{lc}
\hline \multicolumn{1}{c}{ Hasil Analisis } & Observasi \\
\hline Rerata skor ideal (Xi) & 3 \\
Simpangan baku ideal (SBi) & 1 \\
Skor maksimal ideal & 6 \\
Skor minimal ideal & 0 \\
Skor maksimal Observasi & 1 \\
Skor minimal Observasi & 0 \\
\hline Rerata skor aktual & 3,42 (cukup) \\
\hline
\end{tabular}

Tabel 8 menunjukkan rerata skor dimensi produk kreativitas guru fisika yang kreatif berdasarkan hasil observasi dengan kriteria cukup. Secara keseluruhan data dimensi produk kreativitas guru fisika yang kreatif ditunjukkan pada Tabel 9.

Tabel 9. Data Dimensi Produk Kreativitas Guru Fisika

\begin{tabular}{|c|c|c|c|c|}
\hline \multirow[b]{2}{*}{ Kriteria } & \multicolumn{4}{|c|}{ Penilai } \\
\hline & $\begin{array}{c}\text { Diri } \\
\text { Sendiri } \\
\mathrm{F}(\%)\end{array}$ & $\begin{array}{l}\text { Guru } \\
\text { Senior } \\
\mathrm{F}(\%)\end{array}$ & $\begin{array}{l}\text { Siswa } \\
\mathrm{F}(\%)\end{array}$ & $\begin{array}{c}\text { Observas } \\
\mathrm{F}(\%)\end{array}$ \\
\hline Sangat baik & $1(8,33)$ & $1(8,33)$ & 0 & $2(16,67)$ \\
\hline Baik & $4(33,33)$ & $4(33,33)$ & $7(58,33)$ & $4(33,33)$ \\
\hline Cukup & $7(58,33)$ & $6(50)$ & $5(41,67)$ & $5(41,67)$ \\
\hline Kurang & 0 & $1(8,33)$ & 0 & $1(8,33)$ \\
\hline Sgt. Kurang & 0 & 0 & 0 & 0 \\
\hline Rerata & Cukup & Cukup & Cukup & Cukup \\
\hline
\end{tabular}

Tabel 9 menunjukkan bahwa dimensi produk kreativitas guru fisika yang kreatif berdasarkan penilaian diri sendiri, guru senior, siswa, dan observasi dengan hasil persentase kriteria cukup, sehingga secara keseluruhan dapat disimpulkan bahwa pada kompetensi masih tergolong cukup.

\section{Dimensi Kepribadian Guru yang Kreatif}

Data reflektif terhadap guru dalam pembelajaran fisika berbasis creative skill pada dimensi kepribadian diperoleh melalui lembar angket disajikan pada Tabel 10.

Tabel 10. Data Dimensi Kepribadian Guru yang Kreatif

\begin{tabular}{lccc}
\hline \multicolumn{1}{c}{ Hasil Analisis } & $\begin{array}{c}\text { Diri } \\
\text { Sendiri }\end{array}$ & $\begin{array}{c}\text { Guru } \\
\text { Senior }\end{array}$ & Siswa \\
\hline Rerata skor ideal (Xi) & 12,5 & 12,5 & 12,5 \\
Simpangan baku ideal & 2,5 & 2,5 & 2,5 \\
(SBi) & & & \\
Skor maksimal ideal & 20 & 20 & 20 \\
Skor minimal ideal & 5 & 5 & 5 \\
Skor maksimal angket & 4 & 4 & 4 \\
Skor minimal angket & 1 & 1 & 1 \\
\hline Rerata skor aktual (X) & 16,25 & 15,75 & 15,91 \\
\hline
\end{tabular}




(Baik) $\quad$ (Baik) $\quad$ (Baik)

Point satu (rerata skor ideal) sampai dengan enam (skor minimal angket) terlihat nilainya sama tetapi rerata skor aktualnya berbeda, hal ini disebabkan karena jumlah butir angket yang diberikan responden itu berbeda-beda. Kriteria berdasarkan penilaian diri sendiri, guru senior fisika, dan siswa disajikan pada Tabel 11.

Data berdasarkan hasil observasi dilakukan sebanyak dua kali pada masing-masing pembelajaran yang diselenggarakan oleh guru fisika. Secara umum data tersebut susuai Tabel 12.

Tabel 11. Kriteria Dimensi Kepribadian Guru yang Kreatif

\begin{tabular}{lc}
\hline Interpretasi & Rentang Skor \\
\hline Sangat Baik & $17<\mathrm{x}$ \\
Baik & $14<\mathrm{X} \leq 17$ \\
Cukup & $11<\mathrm{X} \leq 14$ \\
Kurang & $8<\mathrm{X} \leq 11$ \\
\hline Sangat Kurang & $\mathrm{X} \leq 8$ \\
\hline
\end{tabular}

Tabel 12. Data Hasil Observasi Dimensi Kepribadian.

\begin{tabular}{lc}
\hline Hasil Analisis & Observasi \\
\hline Rerata skor ideal (Xi) & 2,5 \\
Simpangan baku ideal (SBi) & 0,83 \\
Skor maksimal ideal & 5 \\
Skor minimal ideal & 0 \\
Skor maksimal Observasi & 1 \\
Skor minimal Observasi & 0 \\
\hline Rerata skor aktual & 3,75 (Baik) \\
\hline
\end{tabular}

Tabel 12 menunjukkan rerata skor dimensi kepribadian kreativitas guru fisika yang kreatif berdasarkan hasil observasi dengan kriteria baik. Secara keseluruhan data dimensi kepribadian guru fisika yang kreatif ditunjukkan Tabel 13.

Tabel 13. Data Dimensi Kepribadian Guru Fisika

\begin{tabular}{|c|c|c|c|c|}
\hline \multirow[b]{2}{*}{ Kriteria } & \multicolumn{4}{|c|}{ Penilai } \\
\hline & $\begin{array}{c}\text { Diri } \\
\text { Sendiri } \\
\mathrm{F}(\%)\end{array}$ & $\begin{array}{l}\text { Guru } \\
\text { Senior } \\
\mathrm{F}(\%)\end{array}$ & $\begin{array}{l}\text { Siswa } \\
\mathrm{F}(\%)\end{array}$ & $\begin{array}{c}\text { Observasi } \\
\mathrm{F}(\%)\end{array}$ \\
\hline $\begin{array}{l}\text { Sangat } \\
\text { baik }\end{array}$ & $4(33,33)$ & $3(25)$ & $4(33,3)$ & $1(8,33)$ \\
\hline Baik & $4(33,33)$ & $5(41,67)$ & $5(41,67)$ & $9(75)$ \\
\hline Cukup & $4(33,33)$ & $4(33,3)$ & $2(16,67)$ & 0 \\
\hline Kurang & 0 & 0 & 1 & $2(16,67)$ \\
\hline $\begin{array}{l}\text { Sangat } \\
\text { Kurang }\end{array}$ & 0 & 0 & 0 & 0 \\
\hline
\end{tabular}

Tabel 13 menunjukkan bahwa dimensi kepribadian guru fisika yang kreatif berdasarkan penilaian diri sendiri, guru senior dan siswa serta hasil observasi memiliki kriteria baik.

Dimensi Proses Pembelajaran

Data Berdasarkan Lembar Angket

Data Reflektif Terhadap guru dalam pembelajaran fisika berbasis creative skill pada dimensi proses diperoleh melalui angket dapat disajikan pada Tabel 14. Point satu (rerata skor ideal) sampai dengan enam (skor minimal angket) pada Tabel 14 terlihat nilainya sama, tetapi rerata skor aktualnya berbeda, hal ini disebabkan karena jumlah butir angket yang diberikan responden itu berbeda-beda.

Tabel 14. Data Dimensi Proses Pembelajaran Guru yang Kreatif

\begin{tabular}{lccc}
\hline Hasil Analisis & $\begin{array}{c}\text { Diri } \\
\text { Sendiri }\end{array}$ & $\begin{array}{c}\text { Guru } \\
\text { Fisika }\end{array}$ & Siswa \\
\hline Rerata skor ideal (Xi) & 15 & 15 & 15 \\
Simpangan baku ideal (SBi) & 3 & 3 & 3 \\
Skor maksimal ideal & 24 & 24 & 24 \\
Skor minimal ideal & 6 & 6 & 6 \\
Skor maksimal angket & 4 & 4 & 4 \\
Skor minimal angket & 1 & 1 & 1 \\
\hline \multirow{2}{*}{ Rerata skor aktual (X) } & 16,92 & 16,75 & 16,04 \\
& (Baik) & (Cukup & (Cukup) \\
\hline
\end{tabular}

Berikut kriteria dimensi proses pembelajaran kreativitas guru fisika sesuai Tabel 15.

Tabel 15. Kriteria Dimensi Proses Kreativitas Guru yang Kreatif

\begin{tabular}{ll}
\hline Kriteria & Jumlah Skor \\
\hline Sangat Baik & $20,4<\mathrm{X}$ \\
Baik & $16,8<\mathrm{X} \leq 20,40$ \\
Cukup & $13,2<\mathrm{X} \leq 16,80$ \\
Kurang & $9,6<\mathrm{X} \leq 13,20$ \\
\hline Sangat Kurang & $\mathrm{X} \leq 9,60$ \\
\hline
\end{tabular}

Data berdasarkan hasil observasi dilakukan sebanyak dua kali pada masing-masing pembelajaran yang diselenggarakan oleh guru fisika. Secara umum data-data tersebut ditampilkan sesuai Tabel 16.

Tabel 16. Data Observasi Dimensi Proses Pembelajaran

\begin{tabular}{lc}
\hline Hasil Analisis & Observasi \\
\hline Rerata skor ideal (Xi) & 3 \\
Simpangan baku ideal (SBi) & 1 \\
Skor maksimal ideal & 6 \\
Skor minimal ideal & 0 \\
Skor maksimal Observasi & 1 \\
Skor minimal Observasi & 0 \\
\hline Rerata skor aktual & 3,58 (Cukup) \\
\hline
\end{tabular}

Tabel 16 menunjukkan rerata skor dimensi proses kreativitas guru fisika yang kreatif berdasarkan observasi dengan kriteria cukup. 
Secara kese-luruhan data dimensi proses kreativitas guru fisika yang kreatif ditunjukkan pada Tabel 17. Tabel 17 menunjukkan bahwa dimensi proses pembelajaran guru fisika yang kreatif memiliki kriteria baik serta berdasarkan hasil observasi menunjukkan kriteria cukup. Secara keseluruhan reflektif guru fisika dalam pembelajaran berbasis creative skill disajikan pada Tabel 18.

Tabel 17. Data Dimensi Proses Guru Fisika

\begin{tabular}{|c|c|c|c|c|}
\hline \multirow[b]{2}{*}{ Kriteria } & \multicolumn{4}{|c|}{ PENILAI } \\
\hline & $\begin{array}{c}\text { Diri } \\
\text { Sendiri } \\
\mathrm{F}(\%)\end{array}$ & $\begin{array}{l}\text { Guru } \\
\text { Senior } \\
\mathrm{F}(\%)\end{array}$ & $\begin{array}{l}\text { Siswa } \\
\mathrm{F}(\%)\end{array}$ & $\begin{array}{c}\text { Observasi } \\
\mathrm{F}(\%)\end{array}$ \\
\hline $\begin{array}{l}\text { Sangat } \\
\text { baik }\end{array}$ & 0 & $\begin{array}{c}2 \\
(16,67)\end{array}$ & 0 & $1(8,33)$ \\
\hline Baik & $7(58,3)$ & $6(50)$ & $7(58,33)$ & $5(41,67)$ \\
\hline Cukup & $5(41,7)$ & $3(25)$ & $4(33,33)$ & $6(50)$ \\
\hline Kurang & 0 & 0 & 0 & 0 \\
\hline $\begin{array}{l}\text { Sangat } \\
\text { kurang }\end{array}$ & 0 & 1 & 1 & 0 \\
\hline Rerata & Baik & Baik & Baik & Cukup \\
\hline
\end{tabular}

Tabel 18. Data Reflektif Terhadap Guru Baru Fisika

\begin{tabular}{lcccc}
\hline \multirow{2}{*}{ Kriteria } & \multicolumn{4}{c}{ Penilai } \\
& $\begin{array}{c}\text { Diri } \\
\text { Sendiri }\end{array}$ & $\begin{array}{c}\text { Guru } \\
\text { Senior } \\
\text { Fisika }\end{array}$ & Siswa & Observasi \\
\cline { 2 - 5 } Sangat baik & $\mathrm{F}(\%)$ & $\mathrm{F}(\%)$ & $\mathrm{F}(\%)$ & $\mathrm{F}(\%)$ \\
Baik & $6(5,3)$ & $1(8,3)$ & 0 & 0 \\
Cukup & $5(41,7)$ & $6(33,3)$ & $4(33,3)$ & $3(25)$ \\
Kurang & 0 & 1 & 1 & 0 \\
Sangat & 0 & 0 & 0 & 0 \\
Kurang & Baik & Baik & Baik & Baik \\
\hline Rata-Rata & & & & \\
\hline
\end{tabular}

Tabel 18 menunjukkan data keseluruhan tentang reflektif guru baru fisika dalam pembelajaran fisika berbasis creative skill dalam kategori baik.

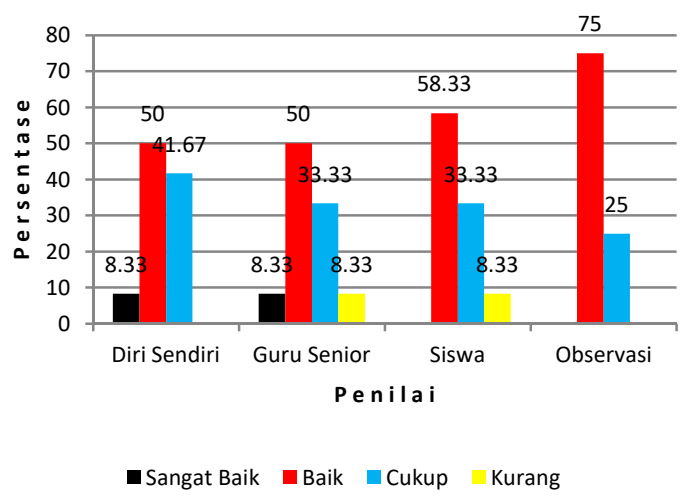

Gambar 5. Refleksi Guru Baru Fisika Lulusan Universitas Sriwijaya dalam Pembelajaran Fisika Berbasis Creative Skill.
Gambar 5 dapat dijelaskan bahwa tingkat reflektif terhadap guru baru fisika lulusan Universitas Sriwijaya dalam pembelajaran fisika berbasis creative skill yang masuk dalam kriteria paling tinggi adalah berdasarkan penilaian secara observasi sebesar $75 \%$, sedangkan yang paling rendah adalah penilaian berdasarkan guru senior fisika sebesar $8,33 \%$ dan siswa sebesar $8,33 \%$ dengan kriteria kurang. Kekurangan ini berda-sarkan analisis data pada dimensi produk yang masuk kriteria cukup serta dimensi proses. Hal ini berarti bahwa guru baru fisika lulusan Universitas Sriwijaya memiliki kelemahan dari segi dimensi produk kreativitas dan proses kreativitas.

\section{SIMPULAN}

Kesimpulan Penelitian ini bahwa secara umum tingkat ketercapaian KKNI level enam guru fisika SMA lulusan Universitas Sriwijaya termasuk dalam kategori baik. Dengan rincian kriteria cukup pada deskriptor pertama dan kriteria baik untuk deskriptor kedua, ketiga, dan keempat. Kelebihan Kompetensi guru fisika lulusan Universitas Sriwijaya berdasarkan KKNI level enam adalah: (a) mampu memanfaatkan ICT dalam pembelajaran fisika; (b) memiliki kompetensi profesional pedagogik yang baik; (c) menguasai kompetensi bimbingan dan konseling dalam pembelajaran; (d) memiliki kompetensi sebagai guru fisika, kompetensi kepribadian, dan memiliki jiwa sosial dalam proses pembelajaran yang baik. Kekurangan kompetensi guru fisika lulusan Universitas Sriwijaya berdasarkan KKNI level enam adalah: (a) dalam kriteria cukup dalam hal kemampuan menggunakan peralatan laboratorium/kit pembelajaran dan menciptakan alat sederhana untuk pembelajaran fisika; (b) kompetensi profesionalnya masih tergolong cukup, dalam hal kemampuan penguasaan materi pembelajaran yang luas dan mendalam; (c) kemampuan dalam menerapkan penelitian pendi-dikan dalam pembelajaran fisika masih tergolong cukup.

Tingkat reflektif terhadap guru dalam pembelajaran fisika berbasis creative skill termasuk dalam kriteria baik namun demikian masih terdapat kekurangan dalam dimensi produk kreativitsas guru dan proses kreativitas guru dalam pembalajaran fisika.

Saran yang dapat diberikan bagi Prodi S1 Pendidikan Fisika di Universitas Sriwijaya, berdasarkan tingkat ketercapaian KKNI level enam adalah dipandang perlu untuk melakukan 


\section{Jurnal Pendidikan Matematika dan Sains, V (1), 2017, 48}

Muhammad Jhoni

evaluasi kurikulum untuk meningkatkan kompetensi yang kategori cukup/kurang, yaitu kompetensi menggunakan peralatan laboratorium, menciptakan alat sederhana untuk pembelajaran fisika, dan kompe-tensi penguasaan metode penelitian pendidikan. bagi guru fisika, diharapkan dapat berusaha meningkatkan kelemahan kompetensinya agar mampu menjadi guru yang profesional dan sesuai dengan kualifikasi standar yang termasuk dalam KKNI level enam.

\section{DAFTAR PUSTAKA}

Afrizon, R., Ratnawulan., \& Fauzi, A. (2012). Peningkatan perilaku berkarakter dan keterampilan berpikir kritis siswa kelas IX MTSN model Padang pada mata pelajaran IPA-Fisika menggunakan model Problem Based Instruction. Jurnal Penelitian Pembelajaran Fisika, 1 (1), 1 - 16.

Print, M. (1993). Curriculum development \& design $\left(2^{\text {nd }} e d.\right)$. NSW, Australia: Allen $\&$ Unwin

Atav, E. \& Altunoglu, B. D. (2010). Pre-service teaches' view about their competencies in biology aplication. Journal of Turkish Science Education, 7 (1), 38 46. Diambil pada tanggal 12 Desember 2013, dari http://www.tused.org.

Bhargava, A. \& Pathy, M. (2011). Perception of student teachers about teaching competencies. American International Journal of Contemporary Research, 1 (1), 77-81. Retrive from http://aijcrnet.com/journals/Vol._1_No_ July_2011/2010.pdf.

Bharvad, A. J. (2010). Curriculum evaluation. International Research Journal, I, 7274.

Bohlinger, S. (2007). Competences as the core element of the european qualifications framework. European Journal of Vocational Training, 42, 96-112.

BPS. (2011). Keadaan ketenagakerjaan 2011. Diakses pada tanggal 8 Februari 2012. www.bps.go.id/brs_file/naker_07nov11. pdf.

Dirjen Dikti. (2010). Buku pedoman kerangka kualifikasi nasional Indonesia, Edisi 1. Jakarta: Kemdikbud.

Federal Ministry of Education and Research Republic of Germany. (2008). The compatibility of the "qualifications framework for german higher education qualifications" with the "qualifications framework for the european higher education area". Jerman: Federal Ministry of Education and Research.

Fuady, A. I., \& Prasetyo, Z. K. (2015). Evaluasi kesesuaian perkuliahan microteaching pendidikan fisika terhadap KKNI di UIN Sunan Kalijaga Yogyakarta. Jurnal Inovasi Pendidikan IPA, 1 (1), 36 - 45.

Higher Education Comprises HBO. (2008). The higher education qualifications framework in the netherlands, a presentation for compatibility with the framework for Qualifications of the European Higher Education Area. Netherlands, Belanda: HBO and WO.

Isaksen, S. G., Puccio, G. J., \& Treffinger, D. J. (2010). An ecological approach to creativity research: profiling for creative problem solving. The Journal of Creative Behavior, 27, 149.

Kaminskienè, L. (2011). Referencing lithuanian qualifications wystem to the european qualifications framework for lifelong learning. Vilnius : Leidybos centras

Light, G. L., Cox, R., \& Calkins, S. (2009). Learner and teaching in higher education. New Delhi: Sage Publication Ltd.

Mardapi, D. (2008). Teknik penyusunan instrumen tes dan nontes. Yogyakarta: Mitra Cendikia Press.

Marinkovic, S., Bjekic., \& Zlatic, L. (2011). Teachers competence as the indicator of the quality and condition education. Serbia: Ministry of Education and science of Republic Serbia.

Markowitsch, J. \& Messserer, K. L. (2008). Development and interpretation of descriptor of the european qualification framework. European Journal of Vocational Training, 42,33 - 58.

Masia, A. (2010). Italian qualifications framework. Cimea, Italia: Ministry of Education, University and Research.

Munandar, U. 2004. Pengembangan kreatifitas anak berbakat. Jakarta: PT Rineka Cipta.

Null, W. (2011). Curriculum from theory to practice. New York: Rowman \& Littlefield Publishers. 
Oliva, P. F. (1992). Developing the curriculum $\left(3^{\text {th }}\right.$ ed.). New York: Harper Collins Publishers.

Presiden RI. (2005). Undang-undang Republik Indonesia Nomor 14 Tahun 2005, tentang Guru dan Dosen.

Rabari, J. A., Indoshi, F. C., \& Omusonga, T. O. (2011). Perceptions of physics students and teachers toward creativity. International Journal of Curren Research, 33, $234-240$.

Smith, M. K. (2013). Curriculum theory and practice. Diakses pada tanggal 23 Februari 2013. http://www.infed.org/ biblio/b-curric.htm.

Subali, B. (2010). Metode penelitian pendidikan biologi. Yogyakarta: FMIPA UNY.

Tan, O. S. (2009). Problem based learning and creativity. Singapore: Cengange Learning.

Cedefop (The European Centre for the Development). (2011). The development of national qualifications frameworks in europe. Luxembourg: Publications Office of the European Union. Diambil pada tanggal 21 November 2013, dari http://www.cedefop.europa.eu/EN.pdf.

Widoyoko, E. P. (2009). Evaluasi program pembelajaran. Yogyakarta: Pustaka Pelajar.

Wijeyaratne. (2012). Sri lanka qualifications framework. Sri Lanka : The World Bank funded Higher Education for Twenty First Century (HETC) Project of the Ministry of Higher Education. Srilanka: Ministry of Higher

\section{PROFIL SINGKAT}

Muhammad Jhoni, S. Pd, dilahirkan di kota Lahat pada tanggal 14 Juni 1984, yang merupakan dosen tetap yayasan di Universitas PGRI Palembang sejak tahun 2012 hingga sekarang. Penulis meraih gelar sarjana (S1) di Program Studi Pendidikan Fisika FKIP Universitas Sriwijaya Palembang. Saran/kritik/ pertanyaan dapat menghubungi 08576485454 dan alamat email m.jhoni66@gmail.com 